\title{
Improving the Osteoblast Cell Adhesion on Electron Beam Controlled $\mathrm{TiO}_{2}$ Nanotubes
}

\author{
Sung Wook Yoon, ${ }^{1}$ Hyun Ju Shim, ${ }^{2}$ and In-Bo Shim ${ }^{1}$ \\ ${ }^{1}$ Department of Nano and Electronic Physics, Kookmin University, Seoul 136-702, Republic of Korea \\ ${ }^{2}$ Hankuk Academy of Foreign Studies, Gyeonggi-do 449-854, Republic of Korea \\ Correspondence should be addressed to In-Bo Shim; ibshim@kookmin.ac.kr
}

Received 7 April 2014; Revised 2 May 2014; Accepted 7 May 2014; Published 28 May 2014

Academic Editor: Seunghan Oh

Copyright ( 2014 Sung Wook Yoon et al. This is an open access article distributed under the Creative Commons Attribution License, which permits unrestricted use, distribution, and reproduction in any medium, provided the original work is properly cited.

\begin{abstract}
Here we investigate the osteogenesis and synostosis processes on the surface-modified $\mathrm{TiO}_{2}$ nanotubes via electron beam irradiation. The $\mathrm{TiO}_{2}$ nanotubes studied were synthesized by anodization process under different anodizing voltage. For the anodization voltage of 15,20 , and $25 \mathrm{~V}, \mathrm{TiO}_{2}$ nanotubes with diameters of 59,82 , and $105 \mathrm{~nm}$ and length of 115,276 , and $310 \mathrm{~nm}$ were obtained, respectively. MC3T3-E1 osteoblast cell line was incubated on the $\mathrm{TiO}_{2}$ nanotubes to monitor the change in the cell adhesion before and after the electron beam irradiation. We observe that the electron beam irradiation affects the number of surviving osteoblast cells as well as the cultivation time. In particular, the high adhesion rate of $155 \%$ was obtained when the osteoblast cells were cultivated for 2 hours on the $\mathrm{TiO}_{2}$ nanotube, anodized under $20 \mathrm{~V}$, and irradiated with $5,000 \mathrm{kGy}$ of electron beam.
\end{abstract}

\section{Introduction}

Due to its unique physical and chemical characteristics as well as its biocompatibility, titanium dioxide $\left(\mathrm{TiO}_{2}\right)$ has been actively researched in various fields such as photocatalysis, sensor, solar cell, and biomaterial [1-4]. The advantage of $\mathrm{TiO}_{2}$ is that it can be easily manufactured in various shapes such as bulk, powder, tube, or grid. In particular, the nanostructured $\mathrm{TiO}_{2}$, offering the extremely high surfacearea-to-volume ratio, can promote cell propagation and reduce rejection symptoms, which is greatly desirable in biomaterial- and implant-related technologies [5]. Among many forms of nanostructured $\mathrm{TiO}_{2}, \mathrm{TiO}_{2}$ nanotube has been reported to strongly affect the propagation of osteoblast cell line, the related ossification process, the mobility of blood cells in blood vessels, and spontaneous differentiation of mesenchymal stem cells [6].

There are a number of $\mathrm{TiO}_{2}$ nanotube synthesis methods such as sol-gel [7] and hydrothermal synthetic process [8], but the quality of the fabricated $\mathrm{TiO}_{2}$ layer such as ruggedness must be considered. In this respect, it has been shown that nanotubes prepared by anodization method [9] have far better features when compared to those from the other two processes above. Also, electron beam irradiation technique can offer a way of improving and/or controlling material characteristics, which can lead to new functionalities and applicability in many technological fields. For example, Jeun et al. [10] have employed the electron beam irradiation to increase the photocatalytic activity in sol-gel based $\mathrm{TiO}_{2}$ and Jun et al. [11] have observed the increase in the conversion rate of $\mathrm{CH}_{4}$ and $\mathrm{CO}_{2}$ by $5 \sim 10 \%$ after electron beam treatment of various catalysts at an absorbed dose of $2 \mathrm{MGy}$.

In this study, we have investigated the effect of the electron beam irradiation on the osteogenesis and synostosis processes on the $\mathrm{TiO}_{2}$ nanotube layer prepared by the anodization process. In particular, we studied the interrelation between the change of $\mathrm{Ti}$ oxidation state and the adhesion characteristics of osteoblast cells.

The work presented here suggests the possible application of surface-modified $\mathrm{TiO}_{2}$ nanotube via electron beam treatment as a bio-osteology restoration material.

\section{Experiments}

The $\mathrm{TiO}_{2}$ nanotubes studied here were fabricated by anodization process. Before anodization, Ti foil (Nilaco, 99.50 purity, 
$0.1 \times 50 \times 50 \mathrm{~mm}, \mathrm{USA}$ ) and platinum (Pt) foil (Daehan, $99.90 \%$ purity, $0.25 \times 50 \times 50 \mathrm{~mm}$ ) were cleaned by ultrasonication in ethanol (Alrdich, 99\% purity, USA) for 3 minutes and dried with nitrogen $\left(\mathrm{N}_{2}\right.$, Daehan Scien. Co, $99.9 \%$ purity, KOR.) gas. The $1,000 \mathrm{~mL}$ of $0.5 \mathrm{~mol} \%$ hydrofluoric acid (HF, Duksan, 48\% purity, KOR.) solution, prepared by mixing $10.4 \mathrm{~mL}$ of HF solution and $989.6 \mathrm{~mL}$ of distilled (DI) water, was used for the anodization electrolyte. The anodization was performed with Pt foil as a cathode and Ti foil as an anode in $0.5 \% \mathrm{HF}$ aqueous solution for 30 minutes with anodization voltage of 15,20 , and $25 \mathrm{~V}$ between them. After anodization, the Ti foil was cleaned with distilled water and dried with $\mathrm{N}_{2}$ gas. Later, the Ti foil was further dried in an electric oven for more than 3 hours at $80^{\circ} \mathrm{C}$. Finally, the dried Ti foil was heattreated in air at $500^{\circ} \mathrm{C}$ for 1 hour.

For the electron beam treatment, the electron beam accelerator (EB-Tech, Model ELV-8, EB tech. KOR.) was used with the beam energy of $1.0 \mathrm{MeV}$, acceleration current of $4 \mathrm{~mA}$, beam dimension of $75 \mathrm{~mm}$ (length) $\times 980 \mathrm{~mm}$ (width), and dose rate of velocity $20 \mathrm{~m} / \mathrm{s}$, resulting in the absorption dose of 0, 50, 500, and $5000 \mathrm{kGy}$.

To monitor the change in the crystal structure of the $\mathrm{TiO}_{2}$ nanotube, X-ray diffractometer (Philips, X'Pert PW1830) was used and field emission scanning electron microscope (FESEM; JEOL, JSM 7401F, Japan) was used to observe the change in the surface morphology before and after electron beam irradiation. The surface oxidation of the nanotube before and after the electron beam treatment was measured by Xray photoelectron spectrometer (XPS; VG microtech, ESCA 2000, England) and analyzed with the binding energy of $\mathrm{O} 1 \mathrm{~s}$.

To understand the cell adhesion on the $\mathrm{TiO}_{2}$ nanotube, MC3T3-E1 mouse osteoblast (CRL-2593, subclone 4, ATCC, Sigma, USA) cell line was incubated. Cultivation was performed by using DMEM culture medium, added with $10 \%$ fetal bovine serum in MC3T3-E1, at $37^{\circ} \mathrm{C}$ for 2,12 , and 24 hours with $\mathrm{TiO}_{2}$ nanotube. With XTT (2,3-bis-(2-methoxy4-nitro-5-sulfophenyl)-2H-tetrazolium-5-carboxanilide, USA) solution added to the incubated medium, ELISA reader was used to verify the change in the reactant. Also, an image analysis program (Image pro plus, Media Cybernetics) was used to count the number of cells incubated on $\mathrm{TiO}_{2}$ nanotube. MTT (3-(4,5-dimethylthiazole-2-yl)-2,5-diphenyl tetrazolium bromide) assay was used to determine the number of surviving osteoblast cells and toxicity during the adhesion of the osteoblast cells on the $\mathrm{TiO}_{2}$ nanotube surface with MTT $5 \mathrm{mg} / \mathrm{mL}$ phosphate buffer solution (PBS, Sigma, USA) as reagents. More specifically, MC3T3-E1 cells were dispensed on $\mathrm{TiO}_{2}$ nanotube surface by $5 \times 10^{4}$ cell/well. Then, cultivation was conducted for 2 and 24 hours for media suction and cleaned with $1 \times$ PBS. Here, $100 \mu \mathrm{g} / \mathrm{mL}$ of MTT solution was added to the media and maintained for 4 hours at $37^{\circ} \mathrm{C}$ in the $\mathrm{CO}_{2}$ incubator. Later, the media were removed and $\mathrm{TiO}_{2}$ nanotube was placed to a new 12-well plate. Dimethyl sulfoxide (DMSO, Sigma Aldrich, USA) was added and well mixed with a pipette to be incubated for 5 minutes. Finally, $200 \mu \mathrm{L}$ of the sample was dispensed into the 96-well and ELISA reader was used to measure the absorbance at $540 \mathrm{~nm}$. The graphs show the average \pm
TABLE 1: Dimensions of $\mathrm{TiO}_{2}$ nanotubes fabricated under different anodization voltage.

\begin{tabular}{lcccc}
\hline $\begin{array}{l}\text { Anodizing } \\
\text { voltage } \\
(\mathrm{V})\end{array}$ & $\begin{array}{c}\text { Inner } \\
\text { diameter } \\
(\mathrm{nm})\end{array}$ & $\begin{array}{c}\text { Out } \\
\text { diameter } \\
(\mathrm{nm})\end{array}$ & $\begin{array}{c}\text { Wall } \\
\text { thickness } \\
(\mathrm{nm})\end{array}$ & $\begin{array}{c}\text { Length } \\
(\mathrm{nm})\end{array}$ \\
\hline 15 & 59 & 102 & 42 & 115 \\
20 & 82 & 124 & 41 & 276 \\
25 & 105 & 162 & 57 & 310 \\
\hline
\end{tabular}

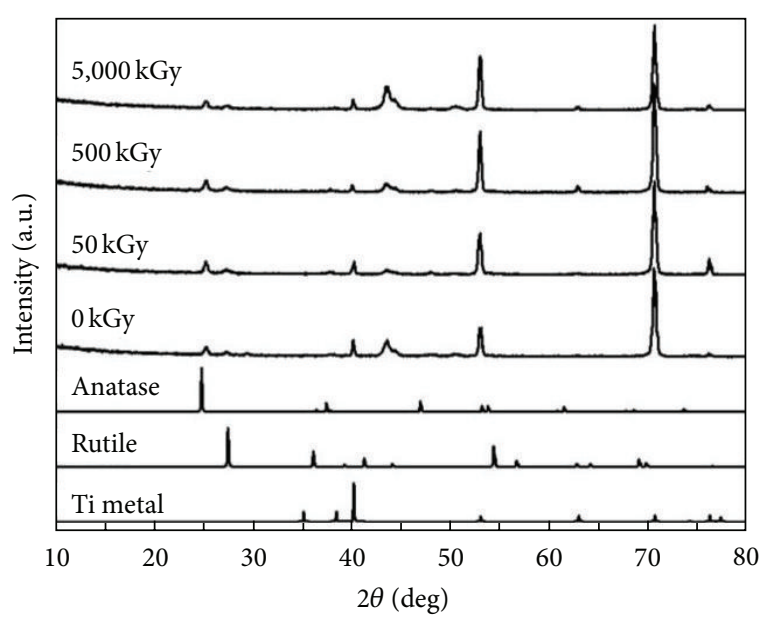

FIGURE 1: XRD patterns of the $\mathrm{TiO}_{2}$ nanotubes with or without the electron beam treatment.

standard error bars associated with the sample size (or $N$ values) shown in a box in the upper portion of each graph.

\section{Results and Discussion}

Figure 1 shows the X-ray diffraction patterns of the $\mathrm{TiO}_{2}$ nanotubes with or without the electron beam treatment. It could be seen that all the samples have typical anatase structures and the anatase structure has been reported to play more important role in cell propagation and formation when compared to other structures [12-14]. The X-ray diffraction patterns observed before and after electron beam irradiation confirm that the amount of the electron beam dose does not affect the crystal structure of $\mathrm{TiO}_{2}$ nanotubes.

Figure 2 shows the FE-SEM images of $\mathrm{TiO}_{2}$ nanotubes fabricated under different anodization voltage between 15 and $25 \mathrm{~V}$, and the resulting dimensions of the nanotubes are listed in Table 1. The scanning electron micrograph shows that the nanotubes are well-arrayed in vertical direction, but the tube diameter varies between 59 and $105 \mathrm{~nm}$ depending on the anodization voltage. Also, one can note that both the diameter and length of the nanotube are proportional to the applied voltage during the anodization process. Comparing between the SEM images before and after the electron beam irradiation, we cannot find any morphological difference. From these results, we found that the osteoblast cell adhesion 


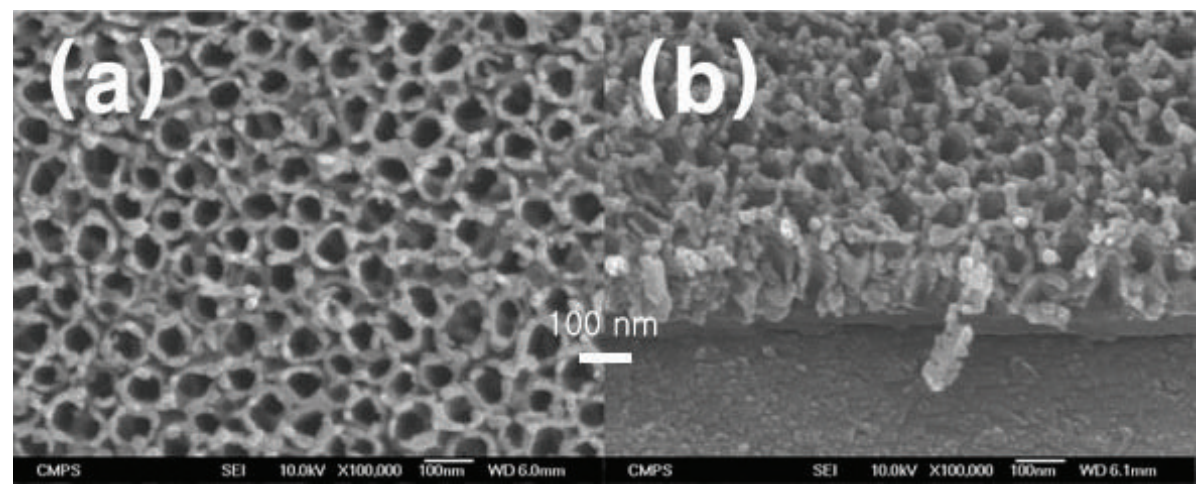

(a)

(b)

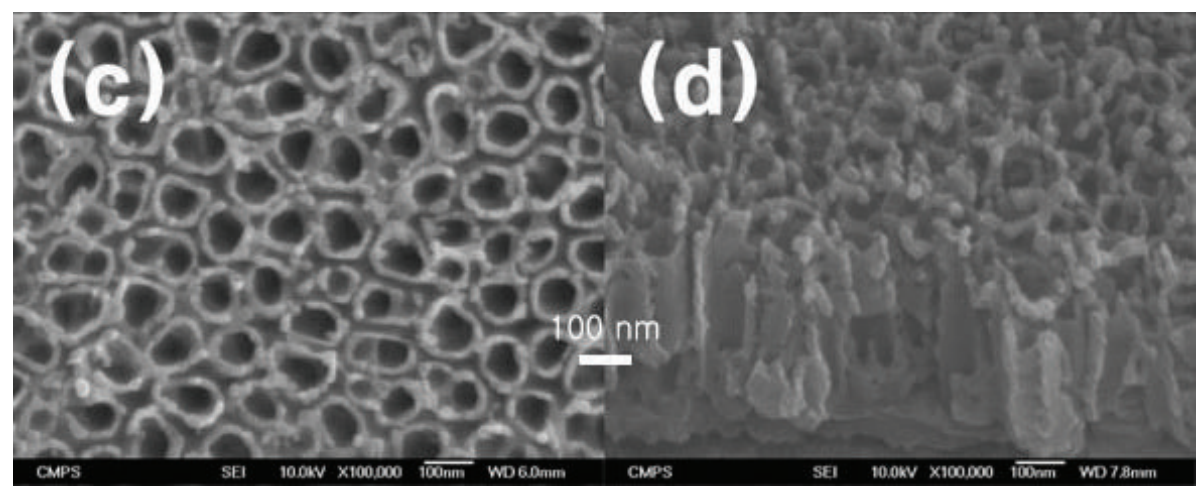

(c)

(d)

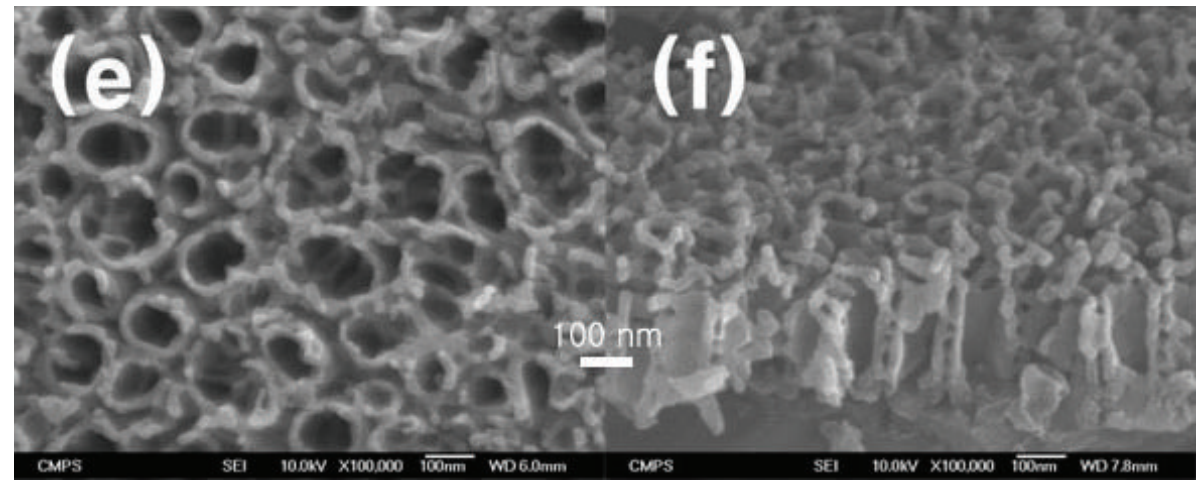

(e)

(f)

FIGURE 2: FE-SEM images of synthesized $\mathrm{TiO}_{2}$ nanotube under different anodization voltage. (a), (c), and (e) show surfaces of the nanotubes, and (b), (d), and (f) display the cross-sectional view of nanotubes fabricated at $15 \mathrm{~V}, 20 \mathrm{~V}$, and $25 \mathrm{~V}$, respectively.

characteristic has not affected the microstructure change by electron beam irradiation. Oh and Jin [15] studied the comparative SEM micrographs of MC3T3-E1 cells cultured on pure Ti versus vertically aligned anatase $\mathrm{TiO}_{2}$ nanotube. The adhesion/growth of osteoblast cells is also significantly accelerated by the topography of the $\mathrm{TiO}_{2}$ nanotubes with the filopodia of the growing cells actually going into the nanotube pores, producing a locked-in cell structure. Figure 3 shows the detailed FE-SEM micrographs of the osteoblast cells cultivated on vertically grown $\mathrm{TiO}_{2}$ nanotubes after electron beam irradiation. Adhesion of osteoblast cells could be observed in all surfaces of the cultivated osteoblast cells on $\mathrm{TiO}_{2}$ nanotubes that had been electron beam irradiated.

The scanning electron micrograph was taken after the cultivation of MC3T3-E1 osteoblast cell line and based on this, the number of cells adhesion on a fixed area of $\mathrm{TiO}_{2}$ nanotube was analyzed (Figure 4). When cultivated on $\mathrm{TiO}_{2}$ nanotubes, high adhesion rate of osteoblast cells was obtained with low applied voltage, since the diameter of the $\mathrm{TiO}_{2}$ nanotube was small with low anodization voltage. Thus, average surface roughness decreases as the nanotube shrinks, which in turn increases the adhesion rate of osteoblast cells. 


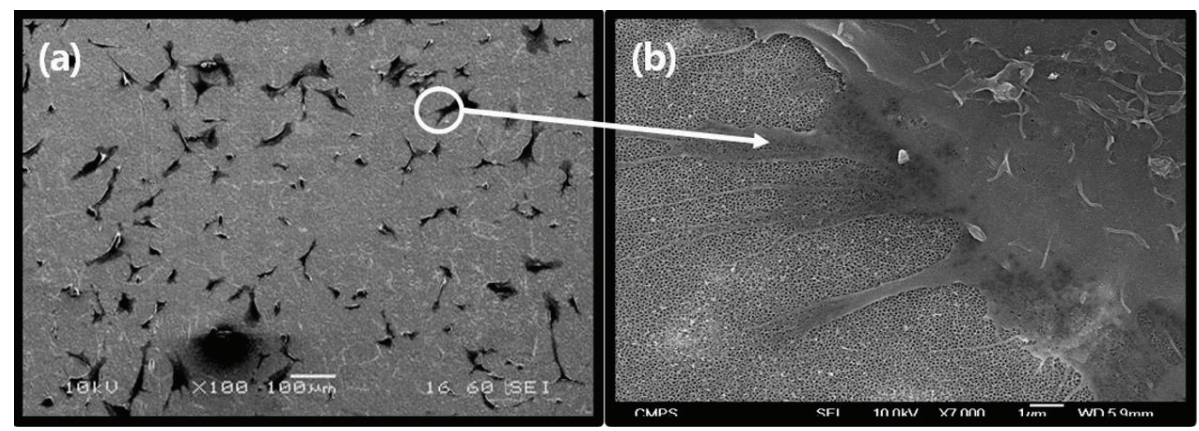

(a)

(b)

Figure 3: (a) Scanning electron micrograph of the osteoblast cell adhered on $\mathrm{TiO}_{2}$ nanotube after electron beam irradiation. (b) The micrograph taken at high magnification.

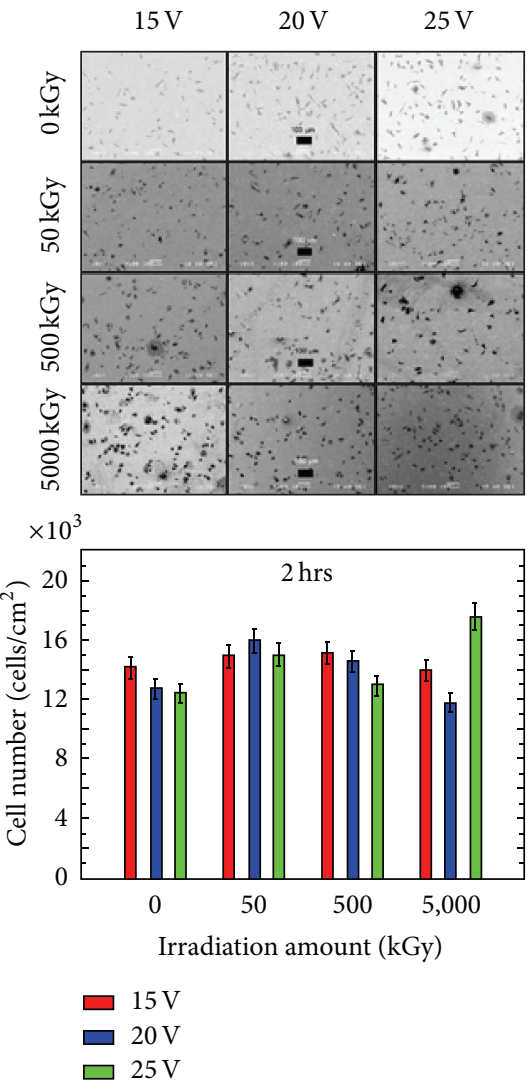

(a)

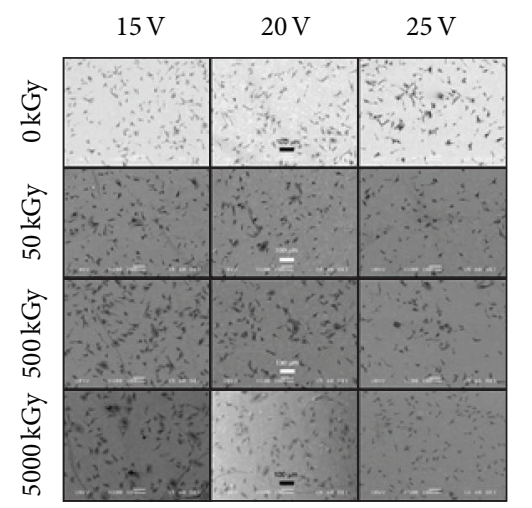

$$
\times 10^{3}
$$

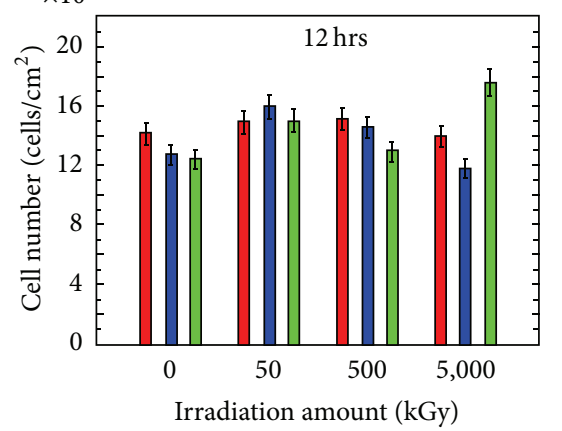

$\square 15 \mathrm{~V}$
$20 \mathrm{~V}$
$25 \mathrm{~V}$

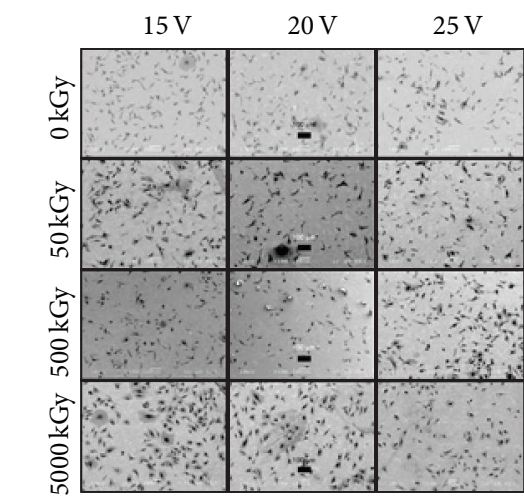

$\times 10^{3}$

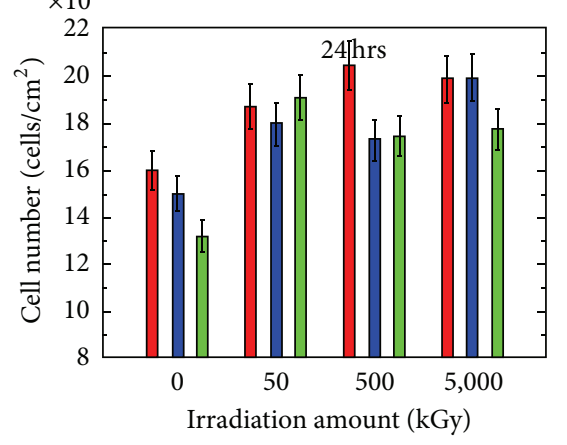

$\square 15 \mathrm{~V}$
$\square 20 \mathrm{~V}$
$\square 25 \mathrm{~V}$

(b)

(c)

Figure 4: Number of cells adhesion on the fixed area of $\mathrm{TiO}_{2}$ nanotube based on the scanning electron micrograph after cultivation of MC3T3-E1 osteoblast cell line for (a) $2 \mathrm{hr}$, (b) $12 \mathrm{hr}$, and (c) $24 \mathrm{hr}$.

With increasing both electron beam dose and cell cultivation time, one can observe that the cell adhesion rate increases. We have obtained the highest adhesion rate of $155 \%$, when the osteoblast cells were cultivated for 2 hours on top of $\mathrm{TiO}_{2}$ nanotube, anodized with $20 \mathrm{~V}$, and irradiated with $5000 \mathrm{kGy}$ of electron beam.

Figure 5 shows the experimentally measured optical density (OD) of osteoblast cells and MTT solution with different cultivation time as well as various electron beam irradiation of $0,50,500$, and $5000 \mathrm{kGy}$ on $\mathrm{TiO}_{2}$ nanotube surface. Regardless of the electron beam irradiation dose, it could be seen that the number of surviving osteoblast cells increases with increasing cultivation time. Also, we have observed that there is no significant change due to the anodization voltage and the detailed structure of $\mathrm{TiO}_{2}$ nanotube.

To understand the observed increase in the adhesion rate, XPS analysis was performed and the condition of 


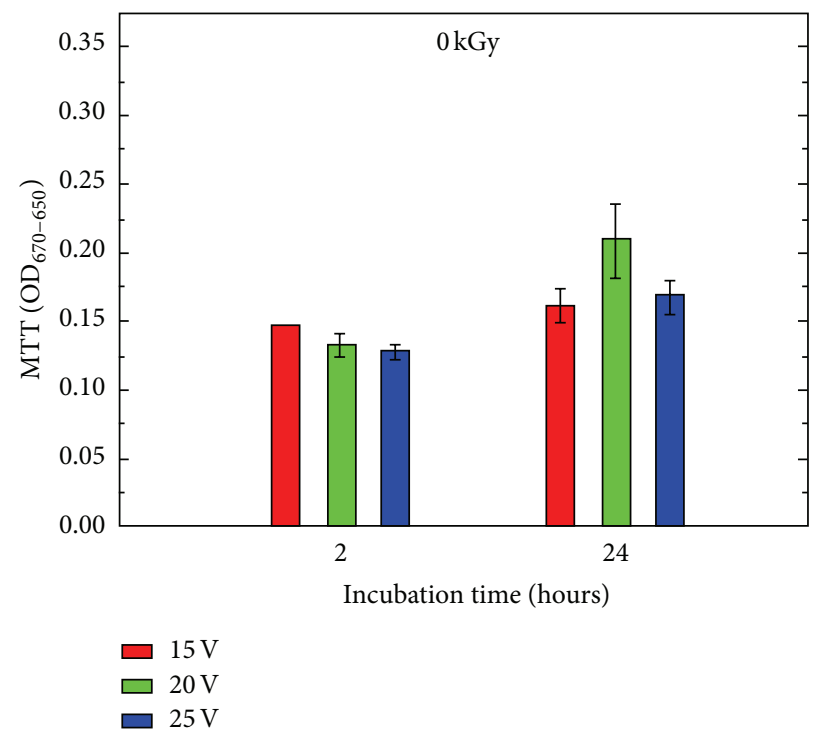

(a)

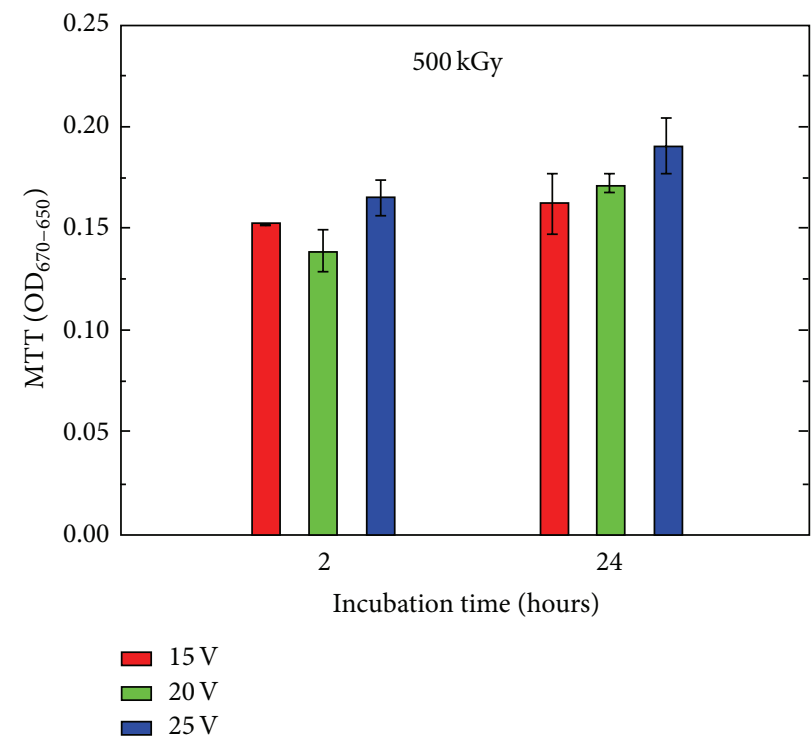

(c)

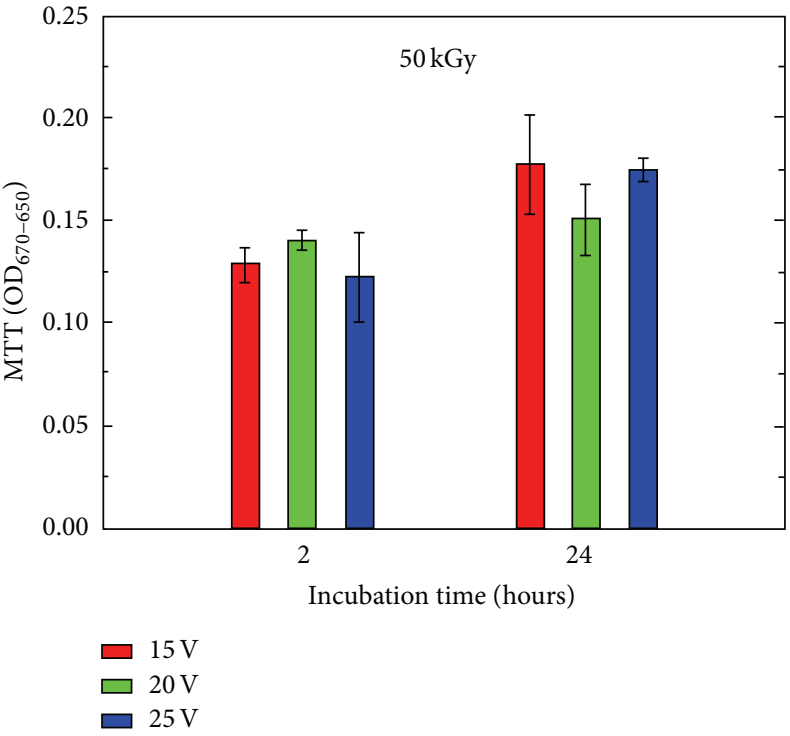

(b)

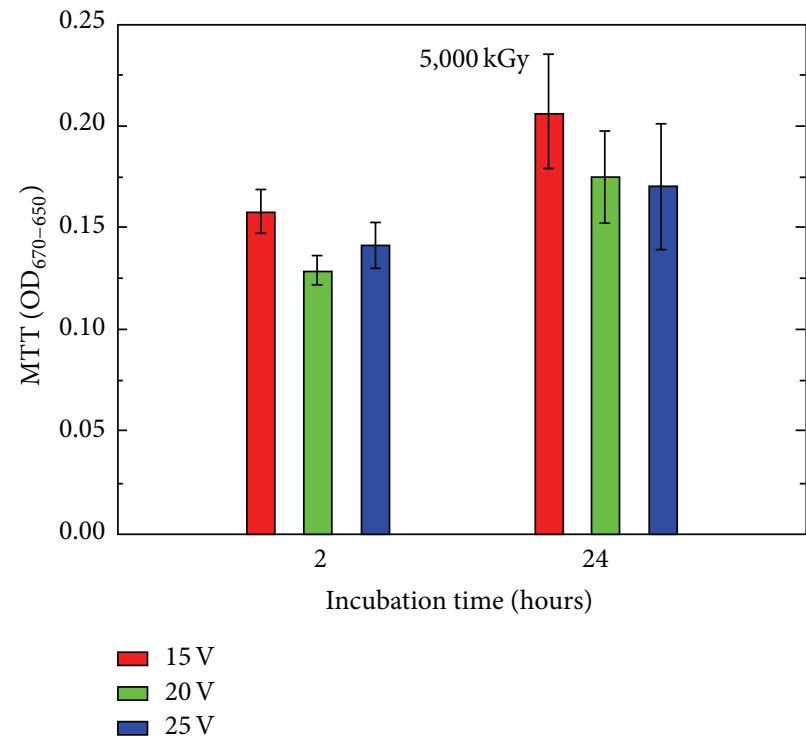

(d)

FIGURE 5: Optical density (OD) of osteoblast cells measured with MTT assay for different electron beam irradiation of (a) 0, (b) 50, (c) 500, and (d) $5000 \mathrm{kGy}$ on $\mathrm{TiO}_{2}$ nanotube surface.

the chemical species on $\mathrm{TiO}_{2}$ nanotube was monitored before and after the electron beam irradiation. Figure 6 shows the XPS analysis of both untreated $\mathrm{TiO}_{2}$ nanotube and $\mathrm{TiO}_{2}$ nanotube irradiated with 5,000 kGy of electron beam. Based on the narrow scan analysis of $\mathrm{O} 1 \mathrm{~s}$ peak, we observed the presence of various forms of the oxidized Ti compound such as $\mathrm{TiO}^{+}, \mathrm{TiO}_{2}{ }^{+}, \mathrm{Ti}_{2} \mathrm{O}^{+}$, and $\mathrm{Ti}_{2} \mathrm{O}_{2}{ }^{+}$. The $\mathrm{O} 1 \mathrm{~s}$ binding energy from the XPS database is $532 \mathrm{eV}$. Therefore, it is impossible to separate the $\mathrm{O} 1 \mathrm{~s}$ peak, existing on the $\mathrm{TiO}_{2}$ nanotube surface, only based on the value of the binding energy. Thus, the peak near $533 \mathrm{eV}$ is caused by different chemical specie, which is most likely to be $\mathrm{OH}$ hydrates in the atmosphere. Therefore, the contribution of $\mathrm{O}$, having the binding energy of $533.3 \mathrm{eV}$, could be considered before and after electron beam irradiation. Here, the area ratio of $\mathrm{O} / \mathrm{O}-\mathrm{H}$ binding was $17085 / 2580$ and there was no significant change before and after electron beam treatment. This suggests that the oxygen existing on $\mathrm{TiO}_{2}$ nanotube surface is not a decisive factor in determining the adhesion rate of osteoblast cells.

To further determine the Ti surface oxidation condition before and after electron beam irradiation, the experimental Ti $2 p$ narrow scan spectra of $\mathrm{TiO}_{2}$ nanotube surfaces were fitted. Before the electron beam treatment, the peak in the spectrum can be separated into Ti $2 \mathrm{P}_{3 / 2}\left(\mathrm{Ti}^{4+}\right)$ with binding energy of $460.60 \mathrm{eV}$ and $\mathrm{Ti} 2 \mathrm{P}_{3 / 2}\left(\mathrm{Ti}^{3+}\right)$ with $461.50 \mathrm{eV}$. However, after the electron beam treatment with 5,000 kGy, 


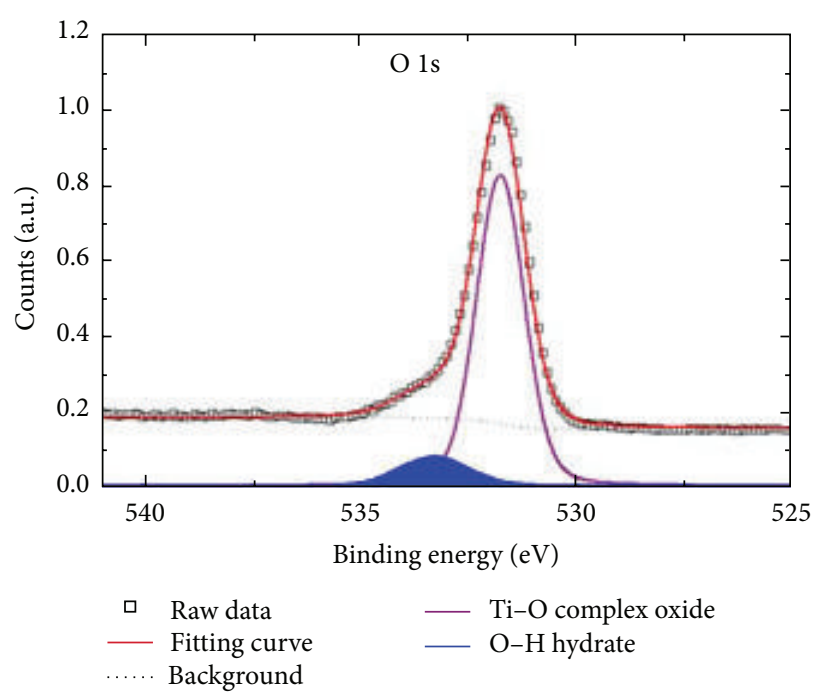

(a)

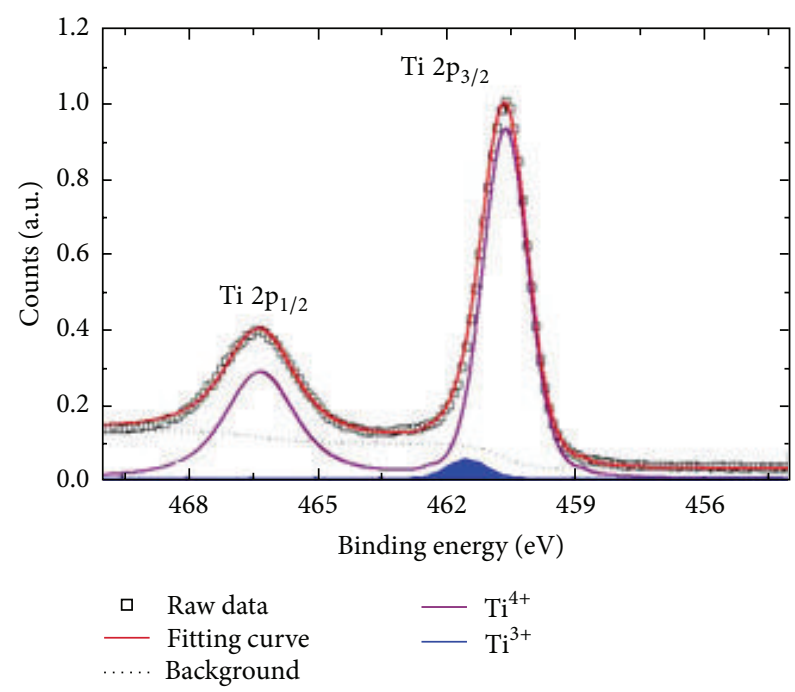

(c)

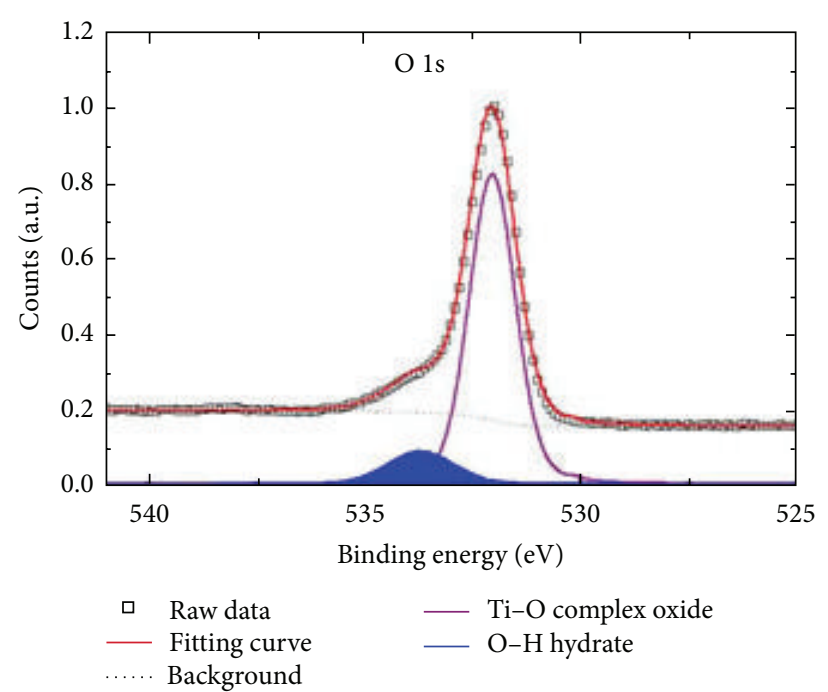

(b)

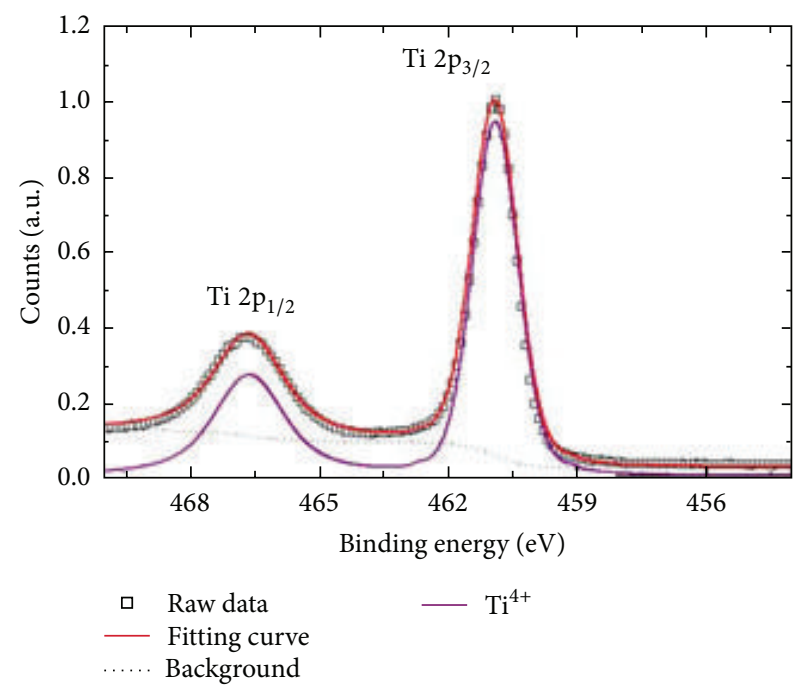

(d)

FIGURE 6: XPS analysis of both untreated $\mathrm{TiO}_{2}$ nanotube and $\mathrm{TiO}_{2}$ nanotube irradiated with 5,000 kGy of electron beam. (a) O $1 \mathrm{~s}$ without irradiation, (b) $\mathrm{O} 1 \mathrm{~s}$ after irradiating with 5,000 kGy, (c) Ti 2p without irradiation, and (d) Ti 2p after irradiating with 5,000 kGy.

the peak corresponds to $\mathrm{Ti} 2 \mathrm{P}_{3 / 2}\left(\mathrm{Ti}^{4+}\right)$ with $460.90 \mathrm{eV}$ and $\mathrm{Ti} 2 \mathrm{P}_{3 / 2}\left(\mathrm{Ti}^{3+}\right)$ with zero binding energy, suggesting the disappearance of Ti $2 \mathrm{P}_{3 / 2}\left(\mathrm{Ti}^{3+}\right)$ after irradiation. These suggest that the electron beam irradiation affects the oxidation of $\mathrm{TiO}_{2}$ nanotube surface and in return, this modification of the Ti oxidation condition leads to the change in the adhesion characteristics of osteoblast cells on $\mathrm{TiO}_{2}$ nanotube surface.

\section{Conclusion}

$\mathrm{TiO}_{2}$ nanotubes were synthesized via anodization method and the size of nanotube was controlled by the anodization voltage. Also, these nanotubes were electron beam irradiated with dose of $0,50,500$, and $5000 \mathrm{kGy}$ and the resulting absorption characteristics of osteoblast cells on $\mathrm{TiO}_{2}$ nanotube were investigated by cultivating MC3T3-E1 osteoblast cells. We have obtained the high adhesion rate of $155 \%$ after cultivating osteoblast cells for 2 hours on the $\mathrm{TiO}_{2}$ nanotube, anodized under $20 \mathrm{~V}$ and irradiated with 5,000 kGy of electron beam. Our experimental XPS measurements suggest that the electron beam irradiation affects the oxidation of $\mathrm{TiO}_{2}$ nanotube surface and in return, this modification of the Ti oxidation condition leads to the change in the adhesion characteristics of osteoblast cells on $\mathrm{TiO}_{2}$ nanotube surface.

\section{Conflict of Interests}

The authors declare that there is no conflict of interests regarding the publication of this paper. 


\section{Acknowledgments}

This research was supported by Basic Science Research Program and Mid-Career Researcher Program through the National Research Foundation of Korea (NRF) Grant funded by the Ministry of Education, Science and Technology (MEST) (2010-0018557), (2010-0022468), (R11-2005048-00000-0, SRC/ERC Program, Center for Materials and Process of Self-Assembly) and in part by research program 2011 of Kookmin University in Korea.

\section{References}

[1] S. K. Kansal, S. Sood, A. Umar, and S. K. Mehta, "Photocatalytic degradation of Eriochrome Black T dye using well-crystalline anatase $\mathrm{TiO}_{2}$ nanoparticles," Journal of Alloys and Compounds, vol. 581, pp. 392-397, 2013.

[2] T. T. Tran, J. Z. Li, H. Feng et al., "Molecularly imprinted polymer modified $\mathrm{TiO}_{2}$ nanotube arrays for photoelectrochemical determination of perfluorooctane sulfonate(PFOS)," Sensor and Actuators B-Chem, vol. 190, pp. 745-751, 2014.

[3] G. W. Zhang, J. L. Sun, J. Q. Wei, H. H. Sun, and J. L. Zhu, "Significantly enhanced photoresponse in carbon nanotube film/ $/ \mathrm{TiO}_{2}$ nanotube array heterojunctions by pre-electroforming," Nanotechnology, vol. 24, no. 46, Article ID 465203, 2013.

[4] X. Xiao, J. Yu, H. Tang, D. Mao, C. Wang, and R. Liu, “ $\mathrm{TiO}_{2}$ nanotube arrays induced deposition of hydroxyapatite coating by hydrothermal treatment," Materials Chemistry and Physics, vol. 138, no. 2-3, pp. 695-702, 2013.

[5] S. Oh, C. Daraio, L.-H. Chen, T. R. Pisanic, R. R. Fiñones, and S. Jin, "Significantly accelerated osteoblast cell growth on aligned $\mathrm{TiO}_{2}$ nanotubes," Journal of Biomedical Materials Research A, vol. 78, no. 1, pp. 97-103, 2006.

[6] J. Park, S. Bauer, P. Schmuki, and K. von der Mark, "Narrow window in nanoscale dependent activation of endothelial cell growth and differentiation on $\mathrm{TiO}_{2}$ nanotube surfaces," Nano Letters, vol. 9, no. 9, pp. 3157-3164, 2009.

[7] T. Kasuga, M. Hiramatsu, A. Hoson, T. Sekino, and K. Niihara, "Formation of titanium oxide nanotube," Langmuir, vol. 14, no. 12, pp. 3160-3163, 1998.

[8] D. V. Bavykin, J. M. Friedrich, and F. C. Walsh, "Protonated titanates and $\mathrm{TiO}_{2}$ nanostructured materials: synthesis, properties, and applications," Advanced Materials, vol. 18, no. 21, pp. 2807-2824, 2006.

[9] D. Gong, C. A. Grimes, O. K. Varghese et al., "Titanium oxide nanotube arrays prepared by anodic oxidation," Journal of Materials Research, vol. 16, no. 12, pp. 3331-3334, 2001.

[10] J.-P. Jeun, D.-W. Park, D.-K. Seo, H.-B. Kim, Y.-C. Nho, and P.H. Kang, "Enhancement of photocatalytic activity of pan-based nanofibers containing sol-gel-derived $\mathrm{TiO}_{2}$ nanoparticles by Ebeam irradiation," Reviews on Advanced Materials Science, vol. 28, no. 1, pp. 26-30, 2011.

[11] J. Jun, J.-C. Kim, J.-H. Shin, K.-W. Lee, and Y. S. Baek, "Effect of electron beam irradiation on $\mathrm{CO}_{2}$ reforming of methane over $\mathrm{Ni} / \mathrm{Al}_{2} \mathrm{O}_{3}$ catalysts," Radiation Physics and Chemistry, vol. 71, no. 6, pp. 1095-1101, 2004.

[12] K. S. Brammer, S. Oh, C. J. Cobb, L. M. Bjursten, H. V. D. Heyde, and S. Jin, "Improved bone-forming functionality on diametercontrolled $\mathrm{TiO}_{2}$ nanotube surface," Acta Biomaterialia, vol. 5, no. 8, pp. 3215-3223, 2009.
[13] S. Oh, K. S. Brammer, Y. S. J. Li et al., "Stem cell fate dictated solely by altered nanotube dimension," Proceedings of the National Academy of Sciences of the United States of America, vol. 106, no. 7, pp. 2130-2135, 2009.

[14] K. S. Brammer, S. Oh, J. O. Gallagher, and S. Jin, "Enhanced cellular mobility guided by $\mathrm{TiO}_{2}$ nanotube surfaces," Nano Letters, vol. 8, no. 3, pp. 786-793, 2008.

[15] S. Oh and S. Jin, "Titanium oxide nanotubes with controlled morphology for enhanced bone growth," Materials Science and Engineering C, vol. 26, no. 8, pp. 1301-1306, 2006. 

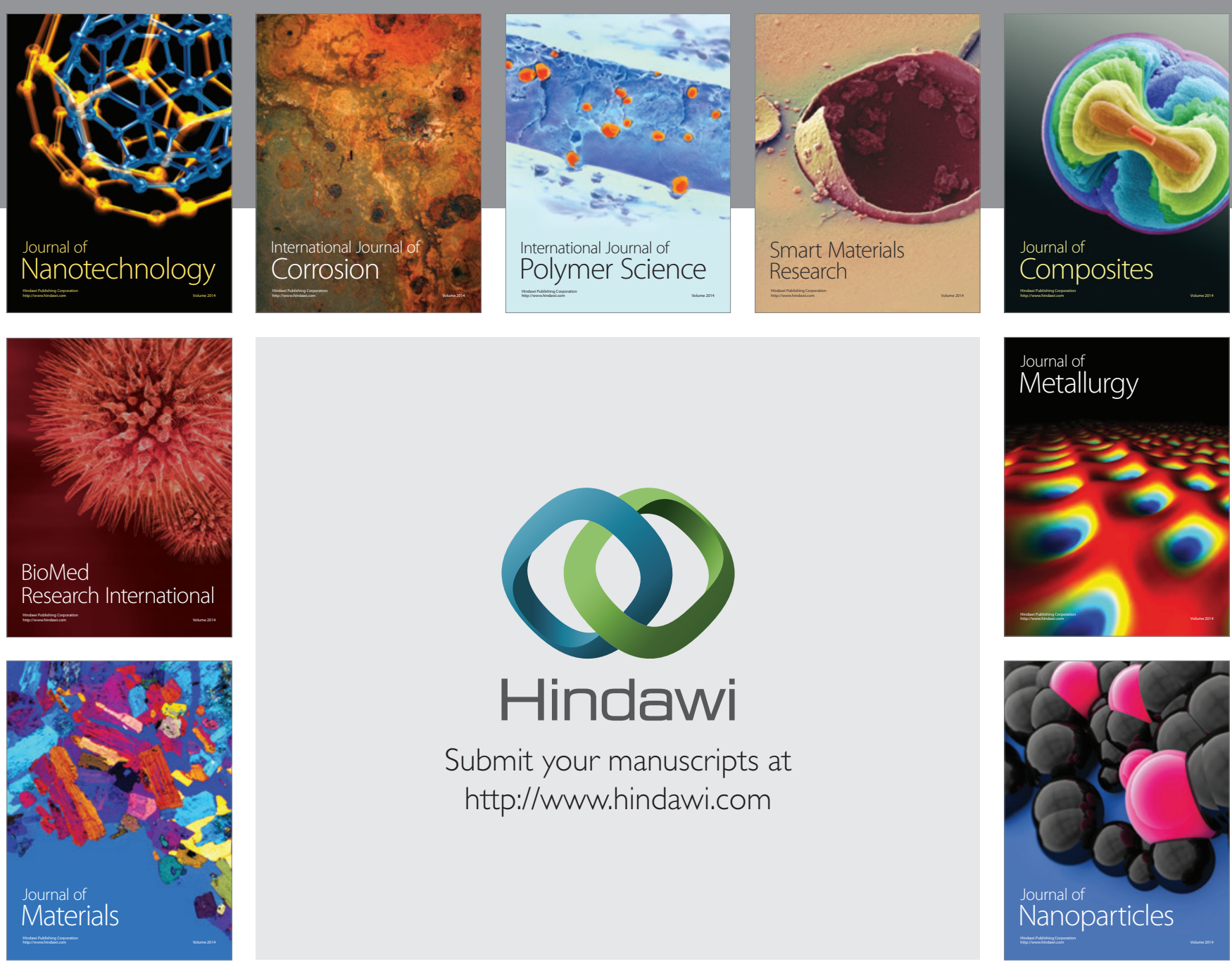

Submit your manuscripts at http://www.hindawi.com
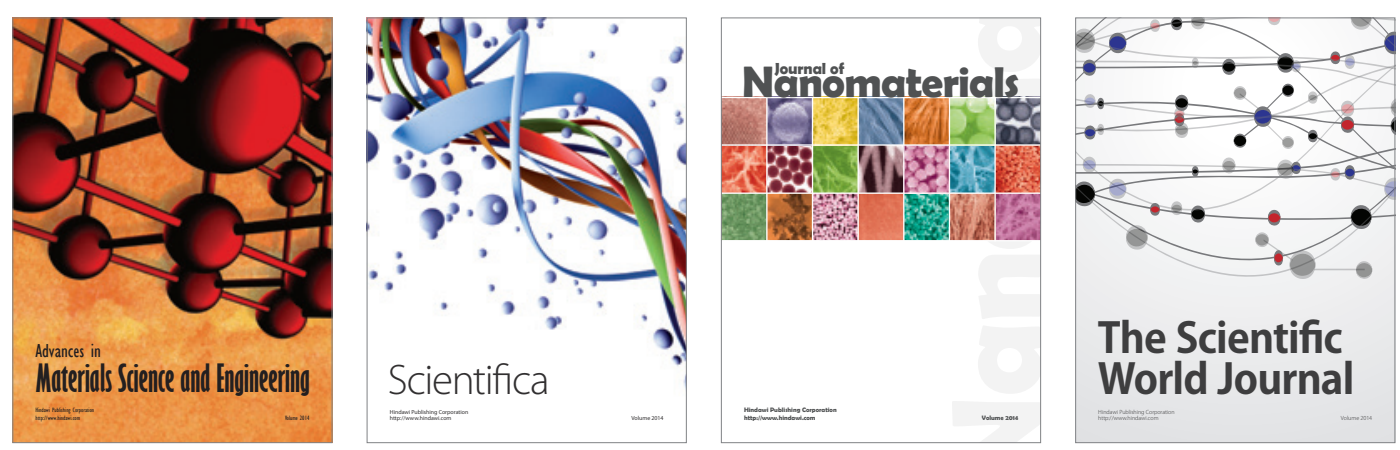

\section{The Scientific World Journal}
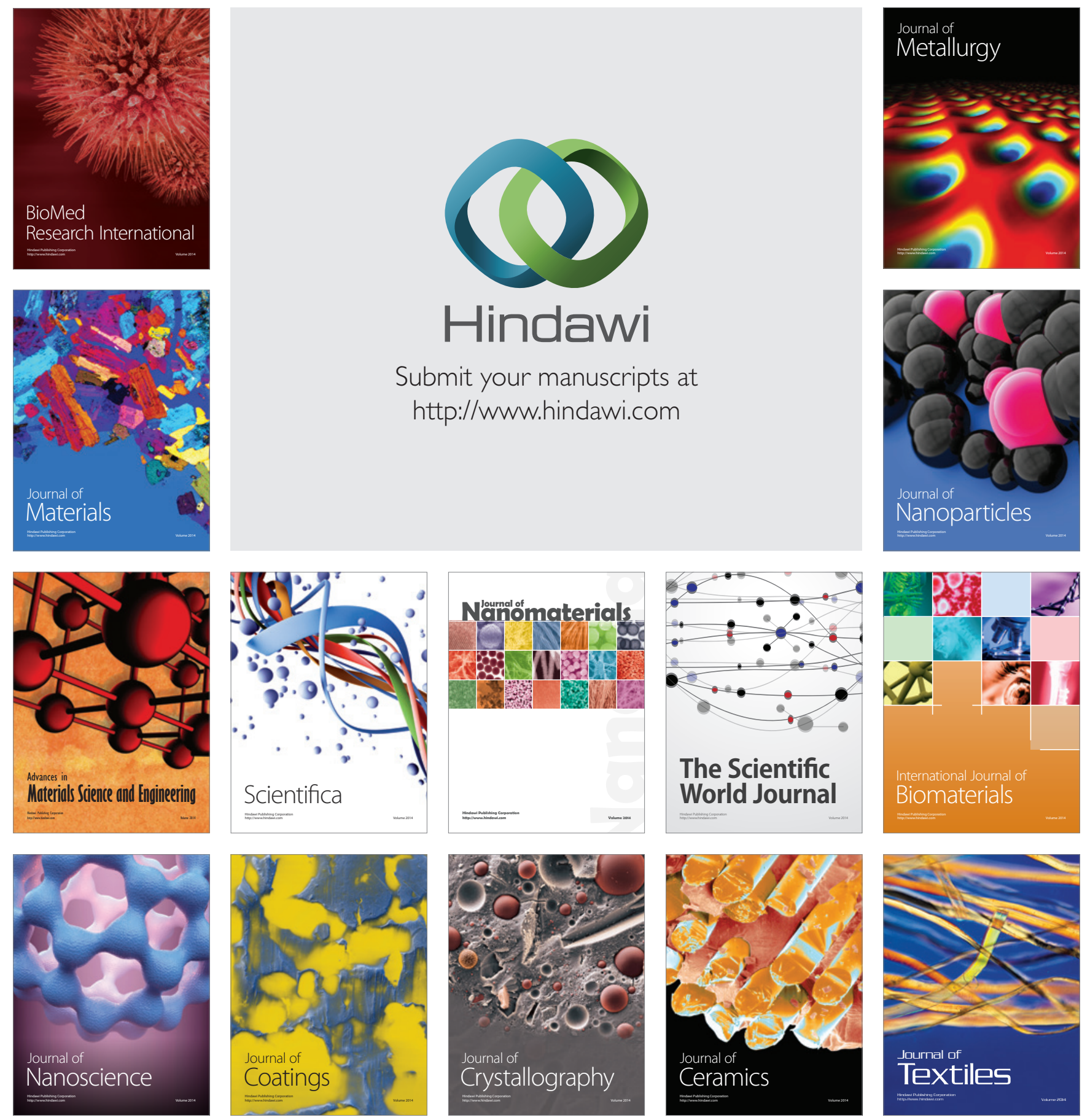